\title{
ALIENATION CHANGES IN FORMATION COMMISSION OF INDONESIAN CONSTITUTION OF1945 \\ (Contemplation Towards The Fifth Amendment)
}

\author{
Lisnawaty W. Badu; \\ Novendri M. Nggilu; \\ Suwitno Y. Imran. \\ Law Faculty, State University of Gorontalo
}

\begin{abstract}
The results of the fourth amendment Constitution of NRI 1945 leaving academic debate, not only in terms of the substance of the constitution that still has weaknesses and needs to be improved and perfected through the fifth amendment of the Constitution of NRI 1945, but also in terms of process changes that lead to refractive mainly against the spirit of Constitutional Commission, Refraction spirit of the Constitutional Commission took place on two points: first, the establishment of the Constitutional Commission which was formed to have lost momentum, as well as the tasks assigned by the Assembly to the Constitutional Commission so minimalist that is limited to conduct a comprehensive review and was impressed merely fix systematize and writing of the Constitution of NRI 1945 which have been produced by the Assembly.
\end{abstract}

Keywords : Alienation; Constitutional Commission; The Constitution of NRI 1945.

\section{A. INTRODUCTION}

Changes in the constitution of Indonesia is often interpreted as the Constitution of the Republic of Indonesia $1945^{1}$ is a necessity, even a "sunatullah" in a democracy. Constitution of the change of the prevalent because of that the dynamics of the community, the soul of the times and the development of constitutional law yangsenantiasa move and change entail a different approach is necessary to amend the constitution. ${ }^{3}$

1 Next will be shortened by the Constitution NRI 1945

2 Constitutional change is something that is prevalent in a democratic country, so Denny Indrayana said constitutional change is sunatullah in the idea of democracy. See Denny Indrayana, 2008, the State Between There and Nothing, Reform State Laws, Kompas, Jakarta, p. 13.

3 Opinions on constitutional change is a response to the social dynamics, spirit of the times, can be seen in Novendri M. Nggilu, 2014, Constitutional Law and
A constitutional change is also something that determines the implementation of constitutional life of a country, even John Burgens argues that constitutional change is something that is very strategic in the constitutional state and determine the constitutional development of a nation, ${ }^{4}$ since changes to the constitution, especially article that govern it, will be able to determine the political actors can make changes to the existing legal norms in the constitution or do redesign of norms that are fundamental. In addition to the norms of a

Theory (Partisipatifdan Populist Constitutional Amendment), First Edition, UII Press, Yogyakarta, p.1.

4 Richard Albert, amending Constitutional amendment Rules, International Journal of Constitutional Law, Boston College Law School Faculty Papers, January 2015 , p. $1-2$ 
constitutional change is a very important part in the constitution, another thing that determines also the process changes. This means that if the norms of constitutional change is an "entrance" constitutionally to change the constitution, then the process of change is "room constitutional" all political actors and the academic and public are gathered devote concepts, ideas about corrections and improvements to the weakness of constitutional contained in the constitution will be changed, ${ }^{5}$ In other words, the process of change will greatly affect the material changes to the constitution, if the constitution is corrected in accordance with the constitutional requirements as well as the "spirit of the age" at the time of changing the constitution is done or not, will depend largely on the process of constitutional change. The results of a good constitutional change, would be greatly affected by the changes are good also. ${ }^{6}$

In the context of the Fourth Amendment to the Constitution of NRI 1945 that occurred in 1999-2002, there was a controversy not only on the status of NRI 1945 Constitution were amended, ${ }^{7}$ the results of the changes made as well as on the process of constitutional change which was considered very thick and colored with high-level political compromise. Yet

5 Rosalind Dixon, Constitutional Amendment Rules: A Comparative Perspective, University of Chicago Public Law and Legal Theory Working Papers, No. 347, May 2011, p. 96

6 Blanc, quoted in Denny Indrayana, 2007, Amendment Act of 1945, Between Myth and Demolition, Mizan Pustaka, Bandung, p. 87

7 Status of changes in question at the time was the validity of the 1945 Constitution to be altered at the time were not previously amended Constitution and confirmed by the Assembly, but designated by President Sukarno by Presidential decree, July $5^{\text {th }}$, 1959. according to Deny Indrayana, the success of reforms of a country, will be determined by the success of the constitutional reform undertaken, and the success of the constitutional reform is determined by the change process is executed. ${ }^{8}$ Process changes made unanimously by the Assembly and strongly colored by political compromise pragmatic short term eventually cause some norms of the Constitution of NRI 1945 rated lose "spirit" of his, such as the authority of the Council which was designed as an institution of mutual control and mutual draw with DPR but institutionally has a very minimalist authority than Parliament. The process of constitutional changes made absolute by the Assembly as an institution institution laden with politics, became the antithesis of the essence of the constitution, because the true nature of the constitution one of satunyaadalah limit the power, but he actually changed by the institution laden with politics.

In the course of change in all four of the Constitution of NRI 1999-2002 1945 , there is a notion that the NRI 1945 amendment to the Constitution was formed a special board or committee to prepare a draft amendment to the Constitution of NRI In 1945, however, the Assembly when it continues Any changes NRI Constitution of 1945 with confidence. Only after the completion of NRI 1945 amendment to the Constitution in 2002, based on the amount of insistence and criticism of the Assembly on the results of the NRI constitutional changes made in 1945, then in 2002 the Assembly established the Commission on the Constitution of the Legislative Act No. I /

8 See Denny Indrayana, 2008, the State Between There and Nothing, Constitutional Reform, Kompas, Jakarta, p. $73-74$ 
MPR / 2002, but the establishment of the Constitutional Commission actually has lost momentum.

After the age of NRI Constitution of 1945 (the result of a change in 1999-2002) has aged 15 years, raise the idea of the fifth amendment of the Constitution of NRI In 1945, it was based on the existence of material weaknesses NRI Constitution of 1945, the other thing apart from the Constitution matter NRI 1945 which needs to be regulated in the Constitution of NRI 1945 through the fifth amendment, ${ }^{9}$ eventually reopen old notes about the idea of formation of the Constitutional Commission. Therefore, before doing the whole set of the fifth amendment of the Constitution of NRI 1945, it is necessary to examine the formation of a constitutional commission in the amendment to the Constitution of NRI 1945 to the fifth amendment, with the boundary problem will be described are, first, Any corrections to the Constitution of NRI 1945 which need to be improved and perfected on the fifth amendment? Second, Do Constitutional Commission before the fifth amendment made will reduce the authority of the Assembly in conducting NRI Constitution Amendment of 1945?

9 Another aspect of the material outside of the Constitution is one of them is the idea of reinforcing the concept of anti-corruption constitution by setting the Anti-corruption Commission and NRI in the Constitution of 1945. This idea emerged and discussed one of them on Legal and Constitutional Debate Opening of regional Timu coupled with the National Seminar Anti-Corruption in Jember Constitution implemented by Constitutional Court with the Faculty of Law, University of Jember, July 25, 2017.

\section{B. DISCUSSION}

\section{Correction on the Result of the Fourth Amendment of the Constitution NRI 1945}

The result of constitutional changes that have been generated through the four stages of the constitutional changes in the period 1999-2002 should be acknowledged to have put some of the principles of constitutionalism in the Indonesian constitution, for example, the principle of the protection of human rights, but must also be recognized that the outcome of the constitutional changes still leave many important notes needs to be corrected and rectified through the fifth amendment. Some parts of the aspects that need to be corrected and improved in the Indonesian constitution can be described as follows:

a. Indonesian legislature institutional design that has not fully reflect aspects of checks and balanches. It was seen from the side of the authority of the DPD which is very minimal compared to the authority of the House of Representatives look very inferior in front of the House of Representatives, whereas DPD has the legitimacy of the people because dipiih directly by the people, even the process of filling the DPD is much heavier than the charging process members of Parliament (compare Article 20, 20A to Article 22D);

b. From the aspect of the executive, the need for strengthening the presidential system to ensure the balance of power between the president and Parliament by streamlining the number of political parties, the two lines in the House 
and opened the way their candidates through individual lines. ${ }^{10}$

c. In the field of the judiciary, the need for structuring judicial system that guarantees the quality of justice with the principle of independence is balanced accountability and ensure public confidence accompanied division of tasks between the Constitutional Court, Supreme Court, and the success of the agenda KY law enforcement and uphold the dignity and the dignity of judges ${ }^{11}$

d. Contemporary conditions of high corruption as well as theoretical and juridical debate about the existence and authority of the Commission in the anti-corruption agenda, raise the idea of anti-corruption constitution that need to be arranged to make sense of the existence of the Commission and its authority in the constitution.

e. The assertion in the Constitution on public participation dalamperubahan NRI Constitution of 1945 and the Constitutional Commission.

\section{Dynamics of Formation Commission In The Fourth Amendment of 1945 Constitution NRI}

When viewed from the side of history, efforts to establish a specialized institution in conducting NRI series of constitutional changes of 1945 have

10 Asshiddiqie, Idea Fifth Amendment of the Constitution of 1945, paper presented at the National Seminar on the 1945 Organized Change Up Cooperation with the Regional Representative Council President University, 28 April 2011, p. 4

11 Ibid. occurred since the time of President Sukarno to the time of President Susilo Bambang Yudhoyono. At the time of President Sukarno, the awareness that the Constitution of NRI 1945 when it was only formed in a short time (18 August 1945) as well as the security situation is unstable, then Sukarno on several occasions have always said that the Constitution of NRI 1945 at the time was Constitution while, ${ }^{12}$ therefore it is necessary to change the constitution. On this basis Soekarno established the constituent assigned exclusively to make changes, although by the end of the Constituent Assembly was dissolved by Sukarno through Presidential Decree On July 5, 1959 in consideration of the Constituent Assembly could not complete the assigned task in accordance with a predetermined target date. ${ }^{13}$

In the period of reform under President BJ. Habibie, push for the constitutional changes 1945semakin strengthened, at least insistence that boiled down to two groups, who want the preparation of a new constitution, as well as groups that want changes to the constitution, not a constitutional amendment. On the basis of this

12 Sobirin Malian, 2001, the Idea of Necessity New Constitution Substitutes 1945, UII Press Yogyakarta. p.70

13 Basic considerations Sukarno in dissolving the Constituent Assembly at the time on the grounds that the Constituent Assembly failed to complete the task caused controversy, one of which was delivered by Adnan Buyung Nasution said that the Constituent Assembly is actually not failed in their duty, but was thwarted. Describe your opinion of the Adnan Buyung Nasution can be seen in Adnan Buyung Nasution, 1995, Aspiration Constitutional Government in Indonesia; Socio-Legal Studies on the Constituent Assembly, graffiti, Jakarta, p. 317320, See Also Novendri Nggilu M., op.cit., P 80 
pressure, then BJ. He formed Panel ${ }^{14}$ which ditugasan to conduct a review of such discontent. The panel study results finally formulate that choice would do is change the constitution and not a renewal, and these changes need to be done by a State Commission on the Constitution Amendment. The work of the Panel submitted to the Assembly and even then stalled because of a change of government. ${ }^{15}$

After the change of government of President BJ. Habibie to Wahid administration, issued Presidential Decree no. 47 of 2001 on the formation of Inquiry Issues committee of the Constitution, this PPMK then conduct a study on the constitutional issue later the results will be submitted to the Assembly for consideration in making changes to amend the Constitution, but before this PPMK completed its work, President Abdurrahman Wahid diimpeachment by the Assembly. ${ }^{16}$

During the reign of Megawati, once advocated that the substance of the constitutional change which emerges in the public space needs to be formulated and crystallized in a systematic and berkeahlianoleh a konstitusi.saynagnya commission, instigation was submitted when the AdHock Committee of the Assembly along with its expert staff is at work preparing further changes, ${ }^{17}$

\footnotetext{
14 The panel consists of Ismail Sunny, Harun alRashid, Sri Soemantri, Bagir Manan, Adnan Buyung Nasution.

15 Bagir Manan, 2004, Progress 1945, UII Press, Yogyakarta, p.21-26

16 Novendri Nggilu M., op.cit., P. 89

17 Ibid., 90-91
}

The swift criticism of the results of the changes made by the Assembly, as well as public pressure against the Commission in the establishment of the Constitution, the Assembly then took the step after the formation of the Constitutional Commission of the Assembly completed the NRI constitutional changes of 1945 in 2002. The establishment of the Constitutional Commission is poured into the MPR Decree 1 / MPR / 2002, which contains; The first, concerning the task of the Constitutional Commission in conducting a comprehensive assessment; second, BP commissioned the Assembly to formulate the composition, position, authority and membership of the Constitutional Commission. ${ }^{18}$ Then MPR MPR issued Decree No.4 / MPR / 2003 concerning the composition, the status, powers and membership of the Constitutional Commission. ${ }^{19}$

The Constitutional Commission according to the author has undergone refraction (bending) the spirit of the community's insistence on the establishment of the Constitutional Commission. Refraction is the most do not include two things: first, the establishment of the Constitutional Commission that has lost momentum, secondly, the task of the Constitutional Commission which is far from the essence of the Constitutional Commission, because only the Constitutional Commission tasked to
18 Decision the MPR, MPR Session End of Term Period 1999-2004, (Secretary General of the Constitutional Committee, 2004), p.14-15.

19 Implementation Report on the amendment of the Constitution of the Republic of Indonesia of 1945 by the Constitutional Commission, p.3-5. 
conduct a comprehensive study. Of refraction on the establishment of the Constitutional Commission, as well as examine their ideas NRI fifth amendment to the Constitution of 1945, the refraction Constitutional Commission which took place in 2002 in alliance tersbut cloned partitions (straightened). Alliances question is, Constitutional Commission should be established before the 1945 amendment to the Constitution of NRI done,

3. Without denying the Constitutional Commission and the Authority MPR Reducing the Constitutional Amendment

There has been concern for some parties that the Constitutional Commission would reduce the authority of the Constitutional Assembly in making changes and assign constitution. It was certainly groundless, if viewed from the experience in some countries, such as South Africa, for example, the change process is done entirely by the Constitutional Drafting Assembly, ${ }^{20}$ both drafts of the constitution, until then assign. If it is paired with Indonesia's Constitution explicitly states that the authority to make changes and the establishment of the Constitution in the hands of the Assembly, then it's hard to us to design exactly the same Constitutional Commission Constitutional Drafting Assembly in South Africa. But we still can form without subjecting the Constitutional Commission and reduce the authority of the Assembly.
If you read the construction construction of Article 37 of the Constitution of NRI 1945, it will be seen that the article contains two dimensions, the first dimension of the authority of institutions, where Article 37 UD NRI 1945 regulates the requisite amendment to the Constitution can be done, as well as the second dimension is the dimension restrictions changes to the constitution, which expressly stated in the article that the special shape of the unitary state can not be changed. In Article 37 of the 1945 Constitution of NRI reflects that constitutional authority in making a change is in the Assembly, even subjects that can propose changes to the leadership of the Assembly has affirmed clearly in the article. Although the constitutional authority to make changes to the constitution is absolutely in the hands of the Assembly, but the Assembly to establish a Constitutional Commission, where the Assembly Commission's own form Konstitusiyang poured into the MPR. In this context, there are two alternatives to choose from, namely (a), the Assembly may establish a Constitutional Commission, which in the determination of its members carried out by the Assembly, (b), the Assembly established the Commission on the Constitution through MPR, but for the selection process and the determination of its members were not monopolized by the Assembly. In other words, the establishment of the selection team whose job is to make the selection of candidates for members of the Constitutional Commission. The selection committee may be filled by members of the DPR, DPD, and as a counterweight is academics. However,

20 Novendri Nggilu M., op.cit., P. 135 
it would be a better team this selection is completely filled by academics, so the nuances of politicization in the determination of the Constitutional Commission members can be avoided. For, if it is not avoided, ${ }^{21}$

Constitutional Commission as mentioned above, can be described in the scheme below: $:^{22}$

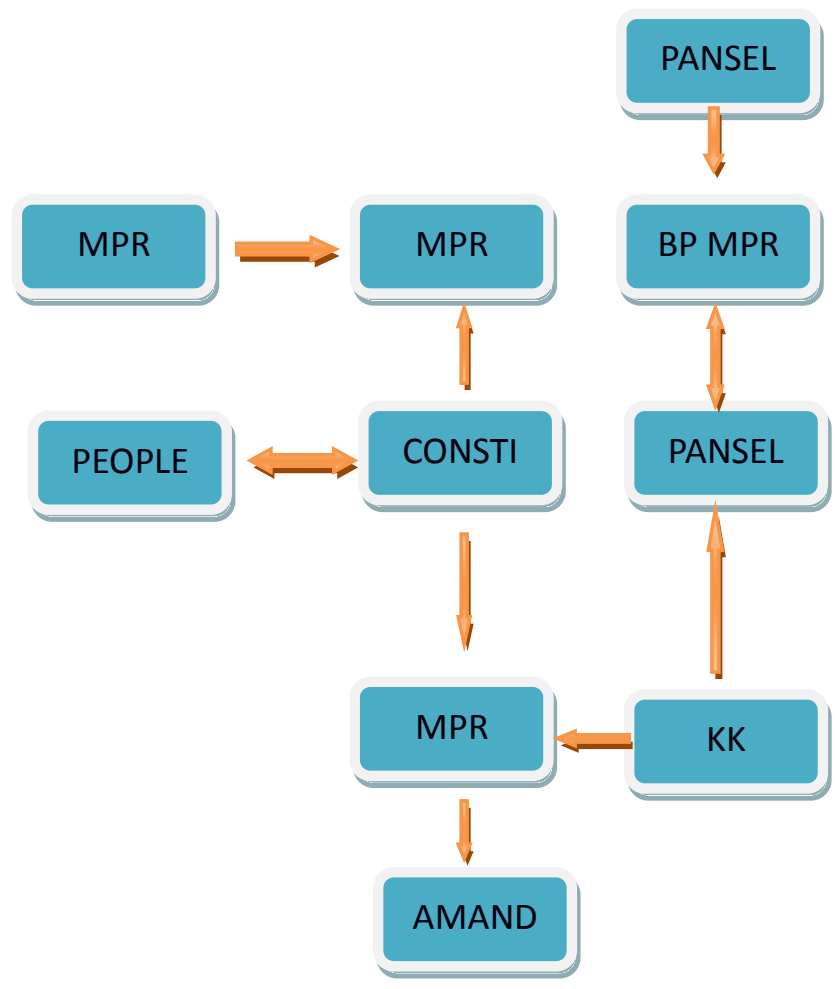

From the above scheme, described about the mechanisms konstitusiyang change process initiated by members of the Assembly

\footnotetext{
${ }^{21}$ Ibid., p. $125-126$

22 Lisnawaty Badu W., et al., 2017, Development
} Model NRI Constitution Amendment 1945 (the Fifth Amendment) Through Constitutional Commission To Achieve The People Constitution, Research at the State University of Gorontalo, p.76 who proposed changing the constitution to the leadership of the Assembly, and the Assembly to implement Article 37 of the 1945 Constitution of NRI filing requirements, discussions and so forth. Having agreed Uslan change and which parts will be changed, then the MPR leaders would assign Assessment Agency of the Assembly to make the arrangement, the position and authority of the constitutional commission, as well as the selection of citizens who want to participate in the selection of the Selection Committee of the Constitutional Commission. After MPR carry out the task, especially on the selection of the selection committee, the selection committee was formed based on the selection results wherewith BP MPR make the selection of Candidates for the Constitutional Commission, idealnyacalon member Constitutional Commission should be free from political affiliation, as well as the selection committee that produced by MPR. Once generated Constitutional Commission members, then the Constitutional Commission of the formulation of the grand design changes to the constitution, taking into account the proposals of members of the Assembly agreed by leaders of the MPR. After the grand design changes to the constitution is formulated, the Constitutional Commission and then conduct a public test of the grand design that has been formulated that, this is done for public participation have been implemented since the formulation of the grand design. The public test should be done on a massive scale, even if it needs to be done is opened the widest possible public discussion of grand space design changes to the constitution. After the formulation of the grand design tela completed, ${ }^{23}$ After the

23 Compare with the mechanism of constitutional changes made by the constitutional committee in Thailand, South Africa, and the Philippines. 
resulting formulation of a draft amendment to the Constitution of NRI In 1945, the Constitutional Commission to submit a report to the Chairman of the Assembly through the MPR, to then be discussed in plenary and set into the Constitution of NRI fifth amendment of 1945 results.

With schema changes referred to above, it is expected that the results of the changes ahead will produce a constitution of the people, because the process of changing the constitution as visualized above, can avoid aggregation shades pragmatic political interests. The Constitution of the people in question contain at least three standard, ${ }^{24}$ First, in the process of change there is the application of the principle of participation, not just involve the community in providing inputs, but also provide space for people to be able to be the subject of control over constitutional changes carried out, so that other aspects which worry about the aggregation of political interests that are pragmatic will obscure the spirit and substance of the changes can be avoided and suppressed. secondly, the substance of the constitution and protect the rights aspect mengakomidir-hakkonstitusional citizens, especially with regard to fundamental rights, such as food, health, environments and other aspects of fundamental rights. Third, the public acceptability of the results of NRI 1945 amendment to the Constitution is very high.

\section{CONCLUSION}

1. The results of the fourth amendment Constitution of NRI 1945 should diakuimasih memilikikelemahan to be refined in further changes, both in terms of strengthening the authority of the DPD which currently seem very inferior in front of the Parliament, strengthening the authority of the Commission as a supervisory institution and enforcement dignity of the judge who is not only limited to judge the environment of the Court Great, but also a judge on the Constitutional Court, as well as anything else that is necessary to be accommodated in accordance with the needs and demands of the "spirit of the times" today, such as the strengthening of anti-corruption constitution in the Constitution of NRI 1945 through arrangements NRI Commission in the Constitution of 1945.

2. Constitutional Commission actually does not conflict with the constitution, and will not reduce the constitutional authority MPRdalam make changes, as long as the Constitutional Commission was established by the Assembly, where its formation is done before changing the constitution is done, do not like the establishment of the Constitutional Commission that occurs in epidemic 2002 which has been losing momentum, besides giving the task to the Constitutional Commission is not just a review of the constitution, but also to formulate a grand design changes, as well as the draft Constitution of NRI fifth amendment of 1945. In the implementation of all phases of the task of the Constitutional Commission, should reflect the application of the principle of public participation, so that the results of the fifth amendment do will bear the people constitution.

${ }^{24}$ Lisnawaty W. Badu, op.cit., P. 80 


\section{BIBLIOGRAPHY}

Adnan Buyung Nasution can be seen in Adnan Buyung Nasution, Indonesia's Constitutional Government aspiration; Socio-Legal Studies on the Constituent Assembly, Jakarta; Graffiti, 1995.

Bagir Manan, Development 1945, Yogyakarta; UII Press, 2004.

Denny Indrayana, Amendments Act of 1945, Between Myth and Demolition, Bandung; Mizan Pustaka 2007.

2008.

Novendri M. Nggilu, Legal and Constitutional Theory (Partisipatifdan Populist Constitutional Amendment), First Edition, Yogyakarta; UII Press, 2014.

Decision the MPR, MPR Session End of Term of Office 1999-2004 period, the Secretary General of the MPR 2004.

Sobirin Malian, Ideas Need for a New Constitution Substitutes 1945, Yogyakarta; UII Press, 2001.

Rosalind Dixon, Constitutional Amendment Rules: A Comparative Perspective, University of Chicago Public Law and Legal Theory Working Papers, No. 347, May 2011.

Asshiddiqie, Idea Fifth Amendment of the Constitution of 1945, paper presented at the National Seminar on the 1945 Organized Change Up Cooperation with the Regional Representative Council President University, 28 April 2011

Lisnawaty Badu W., et al., Development Model NRI Constitution Amendment 1945 (the Fifth Amendment) Through Constitutional Commission To Achieve The People Constitution, Research at the State University of Gorontalo, 2017

Richard Albert, amending Constitutional amendment Rules, International Journal of Constitutional Law, Boston College Law School Faculty Papers, January, 2015. 